\title{
Two Faces of the Literary Avant-Garde: Urmuz and Julio Cortázar. Suggestions for Possible Interpretations
}

\section{Rodica Grigore $^{1}$}

Within the general context of the avant-garde, literary or otherwise, the most important element that informs the modern age following the great example of Arthur Rimbaud, is a clear tendency of replacing, as art's main concern and target, reality as seen in the outside world with its mere possibility. Often compared by the Romanian critics to Kafka, Lautréamont, Alfred Jarry or Charles Cros, Urmuz never knew their literary glory: almost unknown abroad, he is, nevertheless, the one who founded the Romanian avant-garde and is also the most important point of departure for Tristan Tzara. In Urmuz's work, the Bergsonian mechanism of laughter transforms itself into a fragile reality, this kind of humor standing, sometimes, on the very verge of the tragic. But it is obvious that this very situation is also to be found in the histories of the Argentine writer Julio Cortázar, and this essay has as its main purpose a closer examination of the narrative strategies employed by the two authors in order to fully achieve their artistic goals. [Article copies available for a fee from The Transformative Studies Institute. E-mail address: journal@transformativestudies.org Website: http://www.transformativestudies.org (02019 by The Transformative Studies Institute. All rights reserved.]

KEYWORDS: Avant-Garde, Anamorphic Art, Identity, Mask, Mirror, Romanian Literature, Argentine Fiction.

\section{AVANT-GARDE, REALITY, POSSIBILITY}

The most important element of the avant-garde is a clear tendency of replacing, as art's main concern and target, the form of reality (as seen in the outside world) with its mere possibility. The literary pattern was established by Arthur Rimbaud and it was followed by many Western artists. Octavio Paz sees modernity as "a tradition against itself" and the

\footnotetext{
${ }^{1}$ Bio provided at the end of the manuscript. Address correspondence to: Rodica Grigore, Lucian Blaga University of Sibiu, Romania; e-mail: rodica.grigore@gmail.com.

${ }^{2}$ Octavio Paz, Children of the Mire. Modern Poetry form Romanticism to the AvantGarde, Harvard University Press, 1991, p. 3.
} 